\title{
The Dying Bard
}

\section{Author(s): H. Priestley Smith}

Source: The Celtic Review, Vol. 6, No. 21 (Jul., 1909), pp. 64-65

Stable URL: http://www.jstor.org/stable/30070201

Accessed: 09-06-2016 05:11 UTC

Your use of the JSTOR archive indicates your acceptance of the Terms \& Conditions of Use, available at

http://about.jstor.org/terms

JSTOR is a not-for-profit service that helps scholars, researchers, and students discover, use, and build upon a wide range of content in a trusted digital archive. We use information technology and tools to increase productivity and facilitate new forms of scholarship. For more information about JSTOR, please contact support@jstor.org. 
Hector Macneill; and John, son of Malcolm Macneill, gave a bond of manrent to James Macdonald, son and heir of Angus of Islay. In 1618 Hector of Carskeay was placed in charge of the castle of Kilkerran.

\section{The Macneills of Tirfergus}

Among the witnesses to the bond of manrent given in 1594 by the Macneills of Carskeay to James Macdonald were the following persons: Neil Buie Macneill, Tormod Macneill, and Donald Maddir Macneill ; Neil Buie was the representative of the Macneills of Tirfergus, and was succeeded by his son Lachlan. Tormod Macneill and Donald Maddir Macneill were relatives of Neil Buie.

\section{THE DYING BARD}

How long before the night gives way to day?

How long before these glowing embers die away?

Like this poor fire, that, all but spent,

Flickers and fades again; so old and bent,

I know that I must die.

An hour is left: then when away across the sky

The great black clouds have rolled,

The morn will see me cold.

One hour before the paling day has broke!

One hour before these smould'ring embers cease to smoke!

Come, Harp, and in the last red glow,

The melancholy harmonies shall flow;

For when the night is dead

No elegy will sound to mourn this snowy head.

No one is left behind

To moan, except the wind.

So let thy voice, joined with my parting breath, Tell of the tragic majesty of Death.

With tragic chords the heavy Hand of Fate

Strikes the sobbing Lyre of Life-too late

My weary spirit seems

To wake again; too late there rise those idle dreams

The harmonies recall

Of Love, the greatest tragedy of all. 
Farewell, my loveless life, my lifeless love!

The daylight grows, the world begins to move.

Farewell, O Harp: now we have hurled

Our great death-chords across the world,

'Twere best thou never ring

To lesser hand; with mine I snap the string

And throw the broken lyre

To smoulder on the fire.

H. Priestley Smith.

\section{WHITLEY STOKES}

\section{Richard Henebry}

Death has been sadly decimating the little rank of Keltic scholars of late years. Count Nigra of Italy passed away almost with Dr. Ascoli of Milan and Dr. Bugge of Christiania. Then a thrill of sorrow passed over the learned world at the totally unexpected announcement that John Strachan of the Victoria University, Manchester, had been cut down in his prime, to be renewed all too soon by the mournful news that added the name of Whitley Stokes to the tally of the lamented dead. I wish to write this short notice of the life and labours of Stokes as a tribute to the pure friendship that joined us for nigh twenty years and in some slight discharge of the many obligations I owe him.

Whitley Stokes, C.S.I., C.I.E., D.C.L., LL.D., Honorary Member of the German Oriental Society, and Foreign Associate of the Institute of France, who died in London the 13th of April of the present year, was born in Dublin in 1830. He was of Protestant and English stock, but of a family that, like many others, threw in their lot with the people amongst whom they lived, and are tenderly revered in Irish memory for their emulation of the practice of the early Norman settlers in becoming ipsis Hibernis Hiberniores. The first of his name to come to Ireland was Gabriel Stokes, who is on record as having been an Engineer and Deputy Surveyor in 1735. His son, Gabriel Stokes, D.D., was a distinguished VOL. VI. 